Journal of Teacher Education for Sustainability

vol. 11, no. 1, pp. 18-30, 2009

\title{
IMPLEMENTING THE UNITED NATIONS DECADE ON EDUCATION FOR SUSTAINABLE DEVELOPMENT IN LATVIAN HIGHER EDUCATION
}

\author{
Rudite Grabovska and Jens Grabowski \\ Daugavpils University, Latvia
}

\begin{abstract}
The article analyzes the implementation of aims and tasks of the UN Decade of Education for Sustainable Development (DESD) (2005-2014) in Latvian higher education institutions (HEI). In the first part of the article the general context of DESD and its' objectives that will be necessary to reach in all levels of education systems are characterized. The second part describes the results obtained from the research on five Education for Sustainable Development (ESD) indicators by considering the situation in two state universities and two regional HEI in Latvia. Educational policies, strategies, curricula, documentations, and different activities in higher education were analyzed in the context of the DESD. Evaluation of the situation in Latvian HEI in general permits the authors to conclude that cooperation on ESD in global context is developed better than local initiatives.
\end{abstract}

Key words: sustainable development; education for sustainable development; higher education; teacher education; evaluation; implementation.

\section{Introduction}

Continuing to exploit the Earth at the present rate endangers the existence of future generations. Human beings have a choice and they can make a difference. One of the ways of getting the message across is to support the younger generation in understanding that there are limits to the Earth's exploitation. Innovations in education toward sustainable development (SD) are the key features that need to be strengthened as to ensure sustainability of human life. In this vein, the possibilities for introducing SD in higher education need to be explored (Filho, 2000; Pipere, 2006; Pipere, 2007). This is a process that includes the assessment of existing initiatives and development of new activities that ought to be adapted to different cultural situations.

Sustainability is a creative, balanced and future-oriented process ensuring continual feedback on ecological, economical and social issues from the people dealing with these issues in a constructive dialogue. The United Nations (UN) Decade of Education for Sustainable Development (DESD) urges agents to encourage changes in behaviour that 
create a more sustainable and fairer societies as well as the integration of principles, values, and practices of SD into all aspects of education. These educational efforts will bring about changes in behaviour that, in its turn, will create a more sustainable future for present and future generations. Experience in the implementation of the DESD should be analysed (UNESCO, 2005); assessment of formal, non-formal and informal activities can help to achieve the goals of this Decade and its vision.

A constant monitoring of the initiatives for DESD implementation is needed in every country. The initial context of the implementation of DESD is at the local and national, than global level. The adequate processes of monitoring and evaluation must be put in place from the start. Without that, it will be impossible to know if the process has changed and what differences exist. A key aspect of monitoring and evaluation would be suitable, relevant and measurable indicators at all levels (local, national and global) and for each initiative. Thus, monitoring and evaluation will become an integral part of the new thrusts and directions, which the DESD may stimulate (UNESCO, 2005).

This article describes the results of monitoring and evaluation of implementation of aims and objectives of the DESD in Latvian higher education. Examining the implementation of DESD in Latvia, it is evident that the information on such initiatives in higher education is rather vague and does not reflect the real situation in the field. In the report on the situation of DESD implementation in Latvia (MES, 2007b, p. 11), it is specified that there are activities for enhancing a positive insight of the society as well as for the inclusion of SD in the content of formal, non-formal and informal education at all levels. In order to evaluate the implementation of main approaches to ESD in the educational process, it is necessary to define uniform monitoring criteria.

\section{The UN DESD: introduction to global situation}

The DESD is characterized as a political initiative that could strengthen international cooperation towards the development and sharing of innovative ESD activities and policies. Since 1985, the UN has designated International Decades to draw attention to major issues and to encourage international activities on issues of global importance. The historical benchmarks of the DESD are:

- the UN Conferences on Environment and Development (UNCED) "Earth Summit" in Rio de Janeiro in 1992 where 27 principles of the Rio Declaration on Environment and Development, as well as Agenda 21, were developed and accepted;

- the UN Millennium Summit in 2000, where the Millennium Declaration committed society to a new global partnership to reduce extreme poverty, by setting out a series of time-bound targets later known as the Millennium Development Goals;

- the World Summit on Sustainable Development in Johannesburg 2002 that recommended the UN General Assembly to "consider adopting a Decade of Education for Sustainable Development starting in 2005" (paragraph 117d, Plan of Implementation).

In December 2002, Resolution 57/254 on the UN DESD was adopted by consensus. The UN General Assembly resolution designated UNESCO to lead the Decade and 
develop a draft International Implementation Scheme (IIS) for the DESD. The IIS is a strategic document that focuses primarily on what nations have committed to achieve and to contribute through the DESD and under UNESCO's leadership. This was the result of extensive consultations with United Nations agencies, national governments, different institutions, nongovernmental organizations (NGO), and experts.

The goals and objectives of the DESD and its relation to other key education movements are summarized by the UN General Assembly. The primary goal for the DESD is laid out in the UN General Assembly resolution 59/237 in which it "encourages Governments to consider the inclusion ... of measures to implement the Decade in their respective education systems and strategies and, where appropriate, national development plans” (General Assembly, 2005, p. 2). Furthermore, the General Assembly "invites Governments to promote public awareness of and wider participation in the Decade, inter alia, through cooperation with and initiatives engaging civil society and other relevant stakeholders, especially at the beginning of the Decade" (General Assembly, 2005, p. 2-3).

The overall goal of the DESD is the integration of the principles, values and practices of SD into all aspects of education and learning to encourage changes in behaviour. It emphasizes the importance of partnership in the eventual success of the DESD and outlines how these might contribute at all levels - community, national, regional, international, continental, and global. The DESD at the national level tends to provide an opportunity for refining and promoting the vision of and transition to SD, possible through all forms of education, public awareness and training. The implementation of $\mathrm{SD}$ is important for all formal, non-formal and informal activities, also in higher education.

The objectives for the DESD are to:

- facilitate networking, linkages, exchange and interaction among stakeholders in ESD;

- foster an increased quality of teaching and learning in ESD;

- help countries make progress towards and attain the millennium development goals through ESD efforts;

- provide countries with new opportunities to incorporate ESD into education reform efforts (UN, 2004, p. 2).

These objectives include a strategy that enables us to understand others and ourselves. They assign our relationship with the cultural, economical, natural and social environment, as well as the understanding of it all that is the background for building respect. Through the sense of justice, responsibility, equality, and dialogue the DESD objectives persuade us to adopt behaviours and activities supporting values and principles of SD. As well, interlinked strategies (UNESCO ex, 2005) are proposed for the DESD. They will ensure that change in public attitudes and educational approaches keep pace with the evolving challenges for SD. ESD provides values with respect at the centre respect for others, including those of present and future generations, for difference and diversity, for the environment and for the resources on the planet.

Implementation of the DESD goals and objectives mirror the concern for high quality education and integration of sustainability in the whole curriculum, not as a separate subject. The important perspectives that need to be integrated in the curriculum include peace and human security, human rights, gender equality, cultural diversity and 
intercultural understanding, health, governance, natural resources, environment protection, nature conservation, climate change, rural development, poverty reduction. These perspectives are the features of sustainability that are engaged in all spheres of learning: formal and non-formal, informal learning, community-based organizations and local civil society, the continuum from kindergarten through adult education, the workplace, technical and vocational training, teacher training, higher education, policymaking organizations, and beyond. ESD addresses local as well as global issues and uses the language(s) most common for the learners. The outcomes of the DESD will emerge as new attitudes and values, to inspire decisions and actions, making SD a more attainable ideal.

The DESD is a complex and far-reaching undertaking. The best way to implement changes in education is a transdisciplinary approach (Nicolescu, 1997; Wheeler \& Byrne, 2003; Marinova \& McGrath, 2004) that includes holistic understanding of the world's situation as a starting point for developing a new global consciousness in behaviour and lifestyles. DESD implementation will depend on the strength of stakeholder commitment and cooperation at local, regional, national, and global levels. Networks, coalitions and other partnerships will be the crucial element to reach the goals of DESD in society.

Observing the present situation in Latvia regarding the implementation of the DESD (joint planning and regular information exchange about planned activities) in 2006, the Latvian Ministry of Education and Science, Ministry of the Environment and the UNESCO Latvian National Commission signed a cooperation agreement about building a coordination group on this task (MES, 2008a).

\section{Examining the implementation of DESD in Latvian higher education institutions}

\section{Method}

This part of the paper discusses the indicators and data on implementation of the ESD in Latvian higher education institutions (HEI). As it is mentioned in the report of the Latvian Ministry of Education and Science (MES, 2007b), for the successful realization of the DESD aims and tasks, qualitative research is necessary that would include evaluation of all levels of the education system, as well as of formal, non-formal and informal education activities. In order to promote a better understanding and realization of this process, it is necessary to summarize the best practice examples in education. National documents with regulative function such as the National Strategic Reference Framework 2007-2013 (MF, 2007a), the Conception for Education and Development 2002-2005 (MES, 2002), the Law of Higher Education (MES, 2007a) were the sources of general information.

The sample selected for this study was two state universities (DU, 2008; UL, 2008) who focus on research and education and two regional higher education institutions (RHEE, 2008; LiepU, 2008) in Latvia focusing mainly on teacher education. Higher education in Latvia (MES, 2008b) has been binary system since the Law on Education Establishments sets a difference between academic and professional higher education but it is not strictly institutionalised. Universities and other HEI mostly run both academic and applied professional programmes oriented towards higher professional qualifications. Some years ago the mentioned regional HEI was only teacher education focused.

Only the biggest university (Case 2) in Latvia aims for students from all Latvia, while the other institutions are more attuned to regional needs (see Table 1). 
Table 1. Characteristics of analyzed HEI

\begin{tabular}{lcccc}
\hline \multicolumn{1}{c}{ Main features of institutions } & Case 1 & Case 2 & Case 3 & Case 4 \\
\hline Status & $\begin{array}{c}\text { State } \\
\text { University }\end{array}$ & $\begin{array}{c}\text { State } \\
\text { University }\end{array}$ & $\begin{array}{c}\text { Regional } \\
\text { HEI }\end{array}$ & $\begin{array}{c}\text { Regional } \\
\text { HEI }\end{array}$ \\
\hline Year of foundation & 1921 & 1862 & 1993 & 1954 \\
\hline $\begin{array}{l}\text { Year of elaboration of development } \\
\text { strategy for institution }\end{array}$ & 2001 & 2004 & 2006 & 2008 \\
\hline Number of students & 4219 & 23801 & 3269 & 3302 \\
\hline Number of staff & 535 & 2620 & 299 & 298 \\
\hline $\begin{array}{l}\text { Number of teacher education } \\
\text { programmes }\end{array}$ & 11 & 17 & 12 & 14 \\
\hline
\end{tabular}

The documents on the development of HEI, constitutions of universities and priorities of their development were used as the main sources of data. Documents regulating the studies of higher education, self-assessment reports of teacher education programmes were analysed for their content regarding the activities related to DESD.

In order to get more detailed information for the analysis, results obtained from the analysis of documents were discussed with representatives of the target group (20 experts - programme directors, researchers and lecturers from these four HEI). This sample consisted of 20 randomly selected participants that represent a significant variety of ethnic and national identity, age, position, and work experience. The participants were asked to identify, define and reflect on different aspects of their activities and their experience within the ESD.

The content of documents and data from the discussions was subjected to content analysis (Hsieh \& Shannon, 2005).

\section{Results}

Table 2 displays the expected outcomes, potential indicators and data that could be used to support their verification. This is a starting point for evaluation of each initiative on DESD in HEIs in Latvia.

Table 2. Monitoring and evaluation of DESD activities: Indicators and data (adapted from UNESCO ex, 2005, p. 43-44)

\begin{tabular}{lll}
\hline \multicolumn{1}{c}{ Expected outcomes } & \multicolumn{1}{c}{ Potential indicators } & \multicolumn{1}{c}{ Source of verification } \\
\hline $\begin{array}{l}\text { Assessment of the need for } \\
\text { and role of ESD in HEI } \\
\text { development planning and } \\
\text { documents }\end{array}$ & $\begin{array}{l}\text { SD factored into develop- } \\
\text { ment plans and priorities }\end{array}$ & $\begin{array}{l}\text { Points with ESD or SD } \\
\text { component in develop- } \\
\text { ment planning documents }\end{array}$ \\
$\begin{array}{lll}\text { Growing cooperation } \\
\text { among ESD initiatives }\end{array}$ & $\begin{array}{l}\text { Creation of ESD networks } \\
\text { and alliances, joint prog- } \\
\text { ramming between govern- } \\
\text { ment, HEI and NGOs }\end{array}$ & $\begin{array}{l}\text { ESD in proceedings and } \\
\text { other meeting outputs, } \\
\text { membership of ESD net- } \\
\text { works and alliances, joint } \\
\text { initiatives and partici- } \\
\text { pating in them }\end{array}$ \\
\hline & & $\begin{array}{l}\text { Sequel to Table 2 see on p. 23. } \\
\end{array}$
\end{tabular}


Sequel to Table 2.

Broad public awareness of the nature and principles of SD

The thread of SD woven into education efforts to raise educational quality High-quality materials Relevant materials and methodologies in ESD
Participation in local, practical SD initiatives, events, campaigns

Use of SD themes in
education available in learning situations and learning
Initiatives and levels of participation

HEI with SD in education curricula

Materials, distribution and rates of adoption, in-service teacher

The acquired data was coded according to five expected outcomes suggested by monitoring and evaluation of DESD (see Table 2), and then HEI experience on each outcome/indicator was explored.

\section{Assessment of the need for and role of ESD in HEI development planning and documents}

As argued in national development documents (MF, 2007a) and other national documents with regulative function (MES, 2002; MES, 2007a), one of the strategic aims of education is a cultural, social and economic development of country provided by the highly educated population. Examining the data on the first outcome, the main problems in Latvian higher education illustrating the situation of researchers and academic staff are: inadequate qualification and competitiveness of the labour force, lack of integration of higher education and science, small number of doctoral students ( $1.5 \%$ of students' total number, while $5-6 \%$ in other EU countries), age of the academic staff, and decreasing number of faculty with academic degree (MF, 2007b, p. 21-27; $\mathrm{CM}, 2001)$. As outlined in the Conception of Educational Development for 2002-2005 (MES, 2002), to solve these problems and provide the education in the context of lifelong learning, the main task is "to provide the availability of education and equal education possibilities, because social segregation of several social groups endanger the sustainable development of a society" (p. 14).

Evaluation of documents that regulate higher education shows that the horizontal priorities of National Strategic Reference Framework for 2007-2013 (MF, 2007a) are territorial development, macroeconomic stability, equal possibilities for all, sustainable development, and informed citizens.

The concepts of SD and ESD have not been mentioned in any of the four HEI constitutions, strategic aims and tasks of HEI. Analysis of the outlined priorities proves that while these concepts are not included, synonymous concepts are used instead. For example, one of the HEI goals in Case 1 is to promote the development of entire country, Latgale region, as well as the human wellbeing. HEI mission in Case 2 determines that HEI is a guarantee for the development of Latvia. Key words are integration, consideration of European standards and cultural cooperation. In Case 4 the preservation of traditional knowledge in order to maintain national language, culture and traditions is mentioned as an important aim. 


\section{Growing cooperation among ESD initiatives}

Examining the data on the second outcome in all four HEI, it was discovered that the academic staff of these HEI has participated in a large number of international activities and projects. There are personal contacts with other HEI, NGO and organizations influencing the situation; however, there is no evidence of internal cooperation between the involved institutions.

One of organizations involving all four HEI is the Latvian Council of Environmental Science and Education. This organization includes representatives from different HEI, scientific institutions and ministries and works in the field of SD, environmental science and education.

Cooperation on ESD between HEI and NGOs are in place for all four HEI. Among them are Green Centre Liepaja, Centre for the Baltic Studies and Association of Education for Sustainable Development, which carries out some ESD projects and activities in cooperation with students, academic staff and society.

Concerning the ESD global networks and alliances, the academic staff of HEI in Case 1 has participated in the development of the DESD guidelines (UNESCO, 2005) and their achievements have been acknowledged as examples of good practice of implementation of the DESD (UNESCO, 2007a; UNESCO, 2007b). This HEI is also a member of the Environmental Management for Sustainable Universities (EMSU) and other networks. The Baltic and Black Sea Circle Consortium in Educational Research (BBCC) has been established as an initiative of international cooperation between educational institutions. The task of the BBCC is to serve the DESD (UN, 2004) on two levels of the activities: (a) the general level where the theoretical background of sustainable education is acknowledged and studied and (b) the specific level where SD as a crosscurricular issue is implemented in teacher education.

The HEI in Case 2 strives to intensify different types of exchange and to widen possibilities for internationalization of studies and research by participating in international university organizations and through active membership in networks such as The European University Association, Network of Universities from the Capitals of Europe, Baltic Sea Region Universities Network, CAMPUS EUROPAE and UTRECHT Network.

\section{Broad public awareness of the nature and principles of SD}

Examining the data on the third outcome, it is clear that all four HEI organize conferences that feature SD. For example, the annual international JTET/JTEFS conference "Sustainable Development. Culture. Education." is established as a meeting place of BBCC. In this context, international discussions focused on the content of the terms 'sustainable development', 'culture', 'education' and the integration of their content are conducted.

Other HEI hold annual conferences where SD is one of the featured topics, e.g. International Conference "Environmental Science and Education in Latvia and Europe" organized by the Latvian Council of Environmental Science and Education (LCESE), International Conference "Content of Environmental Education in HEI" organized by the HEI Case 2, annual conference by the HEI Case 2 or International Conference "Society. Integration. Education." organized by the HEI Case 3 and International Con- 
ference "Person. Colour. Nature. Music." held at the HEI Case 1. Frequently, during these conferences the understanding of SD is reduced to a single issue, e.g. the issue of sorting waste. However, it is necessary to look for interconnections that would permit interpretation of the notion of SD in a way that would be comprehensible for an audience of any age or level of expertise.

Several national and international projects have been implemented and followedup. For example, the HEI in Case 2 participated in the 5th and 6th RTD Framework Programmes, EU, UNESCO and other projects, that ensured the integration of studies and research and allowed to develop Centres of Excellence, e.g. UNESCO Department at the Institute for Environmental Studies and Management. Some of these national and international projects at the different HEI contribute to issues of SD within education (BUTC, 2008; DU, 2008; UL, 2008; LiepU, 2008; RHEE, 2008).

In the HEI Case 1, research has been conducted on sustainability in teacher education (formal, non-formal and informal) and educational action research has been elaborated as a research method. Also, research institutes were founded, such as the Institute of Sustainable Education (ISE). The strategic aim of ISE is commitment to meta-curricular issues, the holistic approach to education and ESD. These activities contribute to infusion of the concept of SD in Bachelor, Master and Doctoral programmes in education and management. The fundamental principles for achieving this aim include: (1) complementarity of academic and research activities, (2) integration of meta-curricular, crosscurricular and curricular content, (3) implementation of the issue of sustainability within education, (4) research of regional educational issues, (5) integration of collective and individual frames of reference, and (6) encouragement of creative activities, cooperation and adaptive management.

Another example for HEI Case 1 is the Latgale Sustainable Development Research Institute that focuses on supporting and implementing research in the spheres of conservation of environmental quality, optimization of national economies, exploitation of resources, and implementation of ecological technologies.

These research institutions organize different activities such as conferences, research, projects and publication that promote public awareness of the principles of SD. Various local practical SD initiatives, events and campaigns are organised. The most popular activities are joint work to clean the surroundings and various student initiatives, e.g. surveys, research pilot projects. Though, they should be organised more often and should include wider community. All the ongoing activities need to be a priority of the entire institutions, not merely of separate faculties or individual.

\section{The SD for the quality education}

Examining the fourth outcome, the collection of the data was mainly focused on teacher education programmes implemented in all selected HEI. All preschool and primary school teacher professional study programmes contain courses focusing on themes relevant to $\mathrm{SD}$, such as environmental education or ecological education. Concepts of SD are addressed in Case 3 and ESD is coursework in Case 1. Essential aspect of these study courses is a learning environment that is problem-based, ecocentric and based on social changes, which encourages learners' understanding and positive attitude toward global changes, cultural and biological diversity in the world. 
In terms of experts' discussion, the majority of participants stressed that faculty and students should understand the importance of diversity and inclusion, as well as to be able to identify values, assumptions and ethical systems in order to make their own decisions. Higher education has to emphasize experiential, inquiry-based, problemsolving, interdisciplinary approaches and critical thinking. Curricula need to be developed, including content, materials and tools such as case studies and identification of best practices.

Exploring the study courses with relation to ESD as elaborated in all four HEI, it was found that the course targeting ESD most precisely was designed by the Institute of Sustainable Education at HEI Case 1. There are many other study courses directly or indirectly related to ESD in the HEI Case 2, Case 3, and Case 4, in Riga Technical University, Latvian University of Agriculture and other study programmes at the university and college levels. The environmental aspect dominates the content of many of the courses and usually is understood as environmental protection and nature conservation. Also economic and social aspects are integrated or pointed out. But contrary to environmental education (McKeown \& Hopkins, 2007), in ESD environmental aspect ought to be complemented with the economic, cultural and social aspects of SD. Experts (representatives of the target group) agreed that a course on ESD is necessary in all teacher education programmes. But there is still no definitive answer to the question of whether or not to integrate this subject into the curriculum. The questions, whether this course should be compulsory or optional, how to motivate students to choose the course and what it should contain, are still to be discussed in detail.

\section{High-quality materials and methodologies in ESD}

In general, several academic publications on SD and ESD are developed. Two volumes of the international article collection "Education and Sustainable Development: First Steps toward Changes" (Pipere, 2006; Pipere, 2007) have been published and the international peer-reviewed Journal of Teacher Education for Sustainability (JTET/ JTEFS) was launched in 2001 (ISE, 2008). The mission and major goal of the journal is to serve teachers, teacher educators, educational researchers, and policy makers by providing a platform to broaden the focus of local theoretical and practical approaches to teacher education with a global perspective, thus ensuring the contribution for a sustainable future. In all HEI theoretical elaborations and teaching materials on SD (Kl̦aviņš, 2008; Liepiņa, 2008) are published. Research on ESD is undertaken in Bachelor, Master and Doctoral studies.

To implement ESD in higher education, it is necessary to prioritize ESD issues in national and international policies, and to create training materials available for formal, non-formal and informal educational activities. Shortage of resources impedes publication of more high quality issues.

\section{Discussion}

Many HEI, government agencies, policy makers, and NGOs worldwide have significant impact on reorienting the existing documents and laws, as well as academic and professional educational programmes and community activities toward the aims of DESD. 
Governments began with steps to reorient national educational policies and systems toward ESD. Partnerships between government, institutions, organizations and civil society encourage implementation of SD. It is important to assert for a more intensive and coordinated cooperation on implementation of ESD in accordance with the declarations of the DESD, Vilnius Strategy (UNECE, 2005), UNECE $6^{\text {th }}$ Ministerial Conference in Belgrade (UNECE, 2007) and Ahmedabad Conference (CEE, 2007). It is important to include paragraphs with ESD or SD component in HEI development planning documents; all the ongoing activities need to be the priority of the entire institutions, not merely of separate faculties, institutes or members of academic staff. In general, each institution committed to sustainability has to find its own way of defining sustainability, as Calder and Clugston (2002, p.631) suggest, an institution has to frame its own basic understanding of "(1) the complex environmental, social, and ethical issues that must be addressed to create a sustainable future, and (2) the nature of the political, organizational, and individual responses needed".

Experts in the sphere of ESD from Estonian, German, Latvian, Lithuanian, Russian and Swedish educational institutions, foundations and NGOs highly evaluate the positive achievements of ESD in the Baltic Sea region in their declaration as witnessed during the international conference "Education for Change: From Theory to Practical Action" (BUTC, 2008) and point out the necessity to continue the development. The conference participants underlined the regular examination of experience and ongoing activities in the sphere of ESD and the continuation of initiated discussions by inviting experts and representatives from all educational institutions and interested organizations. International experts encourage setting ESD as a priority in teachers' professional development, inclusion of a course on ESD in all study programmes in teacher education and continual development of this course at all levels of higher education.

The quality of materials and methodologies and educational quality in ESD is of concern, as some academics find the concept of sustainability too abstract and broad (Filho, 2000; Davis, Edmister, Sullivan, \& West, 2003) and generally confine interpretation to their individual disciplines. More comprehensive elaborations in the sphere of ESD have been developed in Case 1 and Case 2 of the presented research, which is related to a greater governmental financial support for research in state universities, the capacity of academic staff and greater experience in international projects.

Evaluation of the situation in Latvian HEI in general permits to conclude that cooperation on ESD in global context is developed better than initiatives in local context. This could be related to the initial political situation and the understanding of the topicality of ESD in Latvian education. There are still many unsolved issues that indicate the areas that need greater governmental support, for example, to advance ESD as a priority in teachers' professional development, educational standards, teacher training curriculum and curriculum of all types and levels of formal, non-formal and informal education, to include ESD as a criteria for course book evaluation and in the content of final national examinations. There are more discussions needed to further address these issues; inviting representatives of all Latvian universities and HEI, as well as other experts and interested institutions would support such endeavours. 


\section{References:}

Baltic University Teachers Community (BUTC). (2008). Conference "Education for Change: From Theory to Practice” materials. September 19, 2008, Riga, Latvia. Retrieved October 10, 2008, from http://www.balticuniv.uu.se/teacher/index.php? option=com docman\&task=cat view\&gid=116\&Itemid $=67$

Cabinet of Ministers (CM). (2001). Nacionālās attīstības plāns [National Development Plan]. Rìga: MK.

Calder, W., \& Clugston, R. (2002). Higher education. In J. C. Dernbach (Ed.), Stumbling toward sustainability (pp. 625-646). Washington, DC: Environmental Law Institute.

Centre for Environment Education (CEE). (2007). The Ahmedabad Declaration 2007: A call to action. Education for life: Life through education. The 4th International Conference on Environment Education, 24 to 28 November, 2007, Centre for Environment Education (CEE), Ahmedabad, India. Retrieved January 31, 2008, from http://www.tbilisiplus30.org/Ahmedabad\%20Declaration.pdf

Daugavpils University (DU). (2008). Daugavpils University. Retrieved February 3, 2008, from www.du.lv

Davis, S., Edmister, J., Sullivan, K., \& West, C. (2003). Educating sustainable societies for the twenty-first century. International Journal of Sustainability in Higher Education, 4(2), 169-179.

Filho, W. L. (2000). Dealing with misconceptions in the concept of sustainability. International Journal of Sustainability in Higher Education, 1, 9-19.

General Assembly. (2005). Resolution adopted by the General Assembly 59/237. United Nations Decade of Education for Sustainable Development A/RES/59/237. Retrieved September 9, 2005, from http://daccessdds.un.org/doc/UNDOC/GEN/ N04/490/48/PDF/N0449048.pdf? OpenElement

Hsieh, H. F., \& Shannon, S. (2005). Three approaches to qualitative content analysis. Qualitative Health Research, 15(9), 1277-1288. DOI: 10.1177/1049732305276687.

Institute of Sustainable Education (ISE). (2008). Institute of Sustainable Education (Daugavpils University, Latvia). Retrieved October 10, 2008, from http://www.ise$\underline{\text { lv.eu }}$

Kḷaviņš, M. (Ed.) (2008). Vides zinātne [Environmental science]. Rīga: LU Akadēmiskais apgāds.

Liepaja University (LiepU). (2008). Liepaja University. Retrieved September 10, 2008, from www.liepu.lv

Liepiṇa, I. (Ed.) (2008). Izglītība pārmain̄ām: Ilgtspējīgas attīstības mācī̌̌anas un mācišsanās rokasgrāmata [Education for change: A handbook of teaching and learning sustainable development]. Rīga, Vides Vēstis.

Marinova, D., \& McGrath, N. (2004). A transdisciplinary approach to teaching and learning sustainability: A pedagogy for life. In Seeking Educational Excellence. Proceedings of the 13th Annual Teaching Learning Forum, 9-10 February 2004. Perth: Murdoch University. Retrieved August 31, 2007, from http://lsn.curtin.edu.au/ tlf/tlf2004/marinova.html

McKeown, R., \& Hopkins, C. (2007). Moving beyond the EE and ESD disciplinary debate in formal education. Journal of Education for Sustainable Development, 1(1), 17-26. DOI: 10.1177/097340820700100107. 
Ministry of Education and Science (MES). (2002). Izglìtības attīstības koncepcija 2002.2005. gadam [The conception of educational development for 2002-2005]. Riga, IZM.

Ministry of Education and Science (MES). (2007a). Augstākās izglìtības likums [Law of higher education]. Riga, IZM.

Ministry of Education and Science (MES). (2007b). Pārskats par esošajām aktivitātēm un pasākumiem, kas tiek istenoti saskaņā ar Apvienoto Nāciju Organizācijas dekādes Izglìtība ilgtspējīgai attīstībai noteiktajiem mērķiem un uzdevumiem [Summary of activities and events in compliance with the goals and tasks of the UN DESD]. Riga, IZM.

Ministry of Education and Science (MES). (2008a). Starptautiskā sadarbība-starpresoru ligumi un to izpildprogrammas [International cooperation - interdepartmental agreements and their implementation]. Retrieved December 9, 2008, from http://izm.izm.gov.lv/starptautiska-sadarbiba/starpresoru-ligumi/info.html\# sadarbibas protokols

Ministry of Education and Science (MES). (2008b). The education system in Latvia. Retrieved March 19, 2009, from http://izm.izm.gov.lv/education/educationsystem.html

Ministry of Finance (MF). (2007a). Valsts stratēgiskais ietvardokuments 2007.-2013. gadu periodam [National Strategic Reference Framework 2007-2013]. Riga, LRFM.

Ministry of Finance (MF). (2007b). Analysis of existing situation for national strategic framework 2007-2013. Annex 1: 21-27, in MF (2007) National Strategic Reference Framework 2007-2013. Riga, LRFM.

Nicolescu, B. (1997). The transdisciplinary evolution of the university condition for sustainable development. Presented at the "Universities' Responsibilities to Society", Bangkok: Chulalongkorn University. Retrieved June 6, 2004, from http://perso.clubinternet.fr/nicol/ciret/bulletin/b12/b12c8.htm

Pipere, A. (Ed.) (2006). Education and sustainable development: First steps toward changes. BBCC/ISE annual collection of articles, Volume 1. Daugavpils: Saule.

Pipere, A. (Ed.) (2007). Education and sustainable development: First steps toward changes. BBCC/ISE annual collection of articles, Volume 2. Daugavpils: Saule.

Rezekne Higher Education Establishment (RHEE). (2008). Rezekne Higher Education Establishment. Retrieved September 23, 2008, from www.ru.lv

UNESCO (2005). Guidelines and recommendations for reorienting teacher education to address sustainability. Education for Sustainable Development. In Action Technical Paper, No. 2, UNESCO Education sector, 23.

UNESCO (2007a). Good practices using the Earth Charter. UNESCO Education for Sustainable Development. In Action Good Practices, No. 3, 157-161.

UNESCO (2007b). Good practices in Education for Sustainable Development: Teacher education institutions. UNESCO Education for Sustainable Development. In Action Good Practices, No. 3, 41-46.

UNESCO ex (2005). UN Decade of Education for Sustainable Development 20052014. International Implementation Scheme 171EX/7. Paris, UNESCO. Retrieved April 9, 2007, from http://unesdoc.unesco.org/images/0013/001390/139023e.pdf

United Nations (UN). (2004). DESD Draft International Implementation Scheme. Paris, UNESCO. 
United Nations Economic Commission for Europe (UNECE). (2005). Vilnius Strategy Education for Sustainable Development in the UNECE Region. Retrieved August 29, 2008, from http://www.unece.org/env/esd/Strategy\&Framework.htm

United Nations Economic Commission for Europe (UNECE). (2007). Ministerial Declaration of the 6th Conference "Environment for Europe" (ECE/BELGRADE. CONF/2007/8) in Belgrade (Serbia), October 10-12, 2007. Retrieved September 21, 2008, from http://www.unece.org/env/esd/belgrade.htm

University of Latvia (UL). (2008). University of Latvia. Retrieved September 23, 2008, from www.lu.lv

Wheeler, K., \& Byrne, J. (2003). K-12 sustainability education: Its status and where higher education should intervene. Planning for Higher Education, 31, 23-29.

\section{Correspondence:}

Dr Rudite Grabovska, Institute of Sustainable Education, Faculty of Education and Management, Daugavpils University, Parades 1, Daugavpils, LV-5400, Latvia. Email: rudite.grabovska@du.lv

Received 20 January 2009; revised version received 1 April, 2009 